Nadwa : Jurnal Pendidikan Islam

Vol. 12, Nomor 2 Tahun 2018

Accredited by Ristekdikti based on Decree No. 51/E/KPT/2017

\title{
Internalization of Tolerance Values in Islamic Education
}

\section{Puspo Nugroho}

IAIN Kudus, Central Java, Indonesia

pusponugroho9@gmail,com

\begin{abstract}
The purpose of this paper is to know the internalization process of religious tolerance values such as tauhid, rahmah, musawah in educational institutions. This study took place in the SMP Muhammadiyah Salatiga, the Junior High School, which using a qualitative approach. The results of this study are that first, to put tolerance values into the curriculum, second, to develop vertical relationships in Allah SWT and horizontal fellow humans, third, to emphasize the implementation of tolerance values in the daily lives of students in realizing Islam rahmatan lil alamin, Fourth, the teacher gives examples of tolerance behavior in the learning process.
\end{abstract}

Keywords: internalization; tolerance; religous; nationalism; peace;

Abstrak

Tujuan tulisan ini ingin mengetahui proses internallisasi nilai-nilai toleransi beragama seperti tauhid, rahmah, musawah di lembaga pendidikan. Penelitian ini mengambil lokasi di Sekolah Menengah Pertama Muhammadiyah Salatiga dengan menggunakan pendekatan kualitatif. Hasil penelitian ini adalah pertama memasukkan nilai-nilai toleransi ke dalam kurikulum, kedua : membangun hubungan vertikal pada Allah SWT dan horizontal sesama manusia, ketiga: menekankan pelaksanaan nilai-nilai toleransi dalam kehidupan sehari-hari siswa dalam mewujudkan Islam rahmatan lil alamin. Ke empat: guru memberi contoh prilaku toleransi dalam proses pembelajaran.

Kata kunci: toleransi; agama; lembaga; nasionalisme; perdamaian;

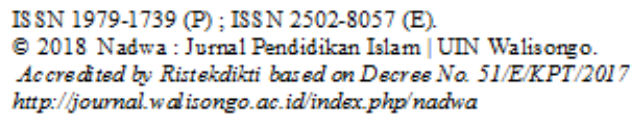




\section{Introduction}

Muslim communities, especially Indonesia, have developed various patterns of thought and ideology. Sometimes religion appears ferociously, far from being polite, and often makes religious people hurt. It does not only against the religion internally but also externally. This phenomenon is supported by rampant arguments through social media in cyberspace. Defamation attacks arguments with various features spread everywhere, justifies, blames each other, and even claims that they are right and the others are wrong. They are easy to say that the others are infidel.

Hate speech fulfills every public space both real and virtual world. If it does not get serious attention, it will certainly have an impact on the younger generations in the future. And of little by little, it will also affect the nation's civilization and make weak nationalism. Even, it is worse but it will undermine the integrity of the Republic of Indonesia.

In formal education, some individuals place religion merely into a formal identity and religion seems to be excluded from world life. Religion that should be used as the foundation of life is only limited to identity, not fully able to color and animate every words and deed. According to the author's perspective, the religious understanding of junior high school students is very minimal. The writer concludes from the observations during interactions in several educational institutions. There are several indicators such as; First, the lack of intensity of students and the spirit of learning religion outside formal education such as pesantren, madrasah diniyah, TPQ or non-formal educations that are taught by kyai, clerics or Qur'an teachers. Religious education is just from the learning process in school is still very lacking. For this reason, the role of informal and non-formal education that studies religion is needed. 
The development of globalization is so fast in affecting the mindset and character of students. If it is not balanced with efforts to develop strong religious attitudes and is not supported by an understanding of moderate and tolerant Islamic religious features, it will certainly make young people not understand the religion well so that it eventually raises radical ideas, intolerance and dehumanism.

There are Phenomena in the society that the existence of certain groups or individuals --- in the words of the author "mendadak agamis" (suddenly religious),---- in terms of attitude, how to dress and even the pattern of thought. (e.g., Javanese) without reflecting a religious symbol at all, but in a matter of a few moments the total 180 degrees changed from style and thought and behavior, of course it prompted a question that influenced how he against religious differences with him; what happen with Fulan? It could be that the he gets guidance and enlightenment towards goodness. Such a thing is not a bad thing. It is a very good change if it is compared to individuals who were initially good, suddenly turned bad. However, what is very unfortunate is that these changes are exclusive and fanaticistic both in terms of culture and differences in religious ways. According to Laurance and E. Berman explained that religious exclusivism has been associated with religious fanaticism which can lead to religious nuances of violence and extremism.1

In addition, within internal religion itself, there are opinion and beliefs differences in the field of jurisprudence or other fields. Differences in beliefs are often used as a pretext for radical actions. For example, the cases of Ambon and Maluku which

1 Laurence R. Iannaccone dan Eli Berman, Religious Extremism: The Good, the Bad, and the Deadly, Public Choice, vol. 128, 2006, https://doi.org/10.1007/s11127-006-9047-7. 
claimed thousands of lives, which reflects the occurrence of coincident social conflicts between religions and tribes.2

Talking about religion, it does not only stop at the vertical level, namely the relationship with God, but religion also regulates human relations that are horizontal in nature and related to the order of life of the people. On the other hand, we need to understand that the pattern of distribution of population based on religion in Indonesia tends not to mix. If each region has a tendency to discriminate and separate from the relationship of life, it will certainly trigger national disintegration.

This phenomenon is caused by the reason. It is as a result of the influence of Dutch colonialism and other influences from European nations such as Portugal, Germany, etc. There were symptoms of religious grouping in the same areas, so that island groups (enclaves) based on religion were formed. Therefore, for example in NTT (East Nusa Tenggara) and also in Papua, it is clearly seen the grouping pattern between Catholics and Protestant people. In North Sumatra, there is a deliberate division of territory between North Tapanuli, the majority of Christians, and South Tapanuli, the majority of whom are Muslims. In Bali Island, the majority of the population is Hindus and speaks Balinese Hinduism. Likewise Sulawesi, for example, in South Sulawesi, the majority are Muslim. There is an 'enclave' of Christians who live in the land of Toraja. In West Kalimantan, the majority of the population is Muslim, but in the city of Singkawang, the majority of the population is Chinese with the majority adhering to Buddhism, Christianity, Catholic, or Konghuchu. And, the number of followers of Islam is a minority.

2 Kholidia Efining Mutiara, "Menanamkan Toleransi Multi Agama sebagai Payung Anti Radikalisme (Studi Kasus Komunitas Lintas Agama dan Kepercayaan di Pantura Tali Akrab)," Fikrah: Jurnal Ilmu Aqidah dan Studi Keagamaan 4, no. 2 (2016): 293-302. 
Similarly, several Dayak tribes in the interior of West Kalimantan and Central Kalimantan are predominantly Protestant or Catholic. Therefore, it is absolute that the issue of the harmony of life among religious communities and internal religious communities must be made a top priority in state policies whenever and under anyone's leadership). 3

The background is certainly as the basic of the importance of building and strengthening the process of tolerance values internationalization, especially through religion-based educational institutions, both formal and non-formal. In this case, education as a formal education institution is still considered appropriate to equip the young generations with it. As part of a community organization, Muhammadiyah has a stake in supporting and strengthening the integrity of the nation, which at present often results in frictions in the society that relate to religion. One of them is through education. Knowing this condition, the writer is interested in studying how Islamic education institutions under the auspices of the Muhammadiyah, in this case Junior High School/SMP Muhammadiyah Salatiga, internalizes the value of religious tolerance as a pillar to strengthen nationalist nationalism.

In its implementation, this study used a qualitative approach (qualitative research). Qualitative research is a research method that describe and analyze the phenomenon of events, social activities, attitudes, beliefs, perceptions, thoughts of both individuals and groups 4. Qualitative research methods are often

3 Jimly Asshiddiqie, "Toleransi Dan Intoleransi Beragama Di Indonesia Pasca REFORMASI," Dialog Kebangsaan tentang "Toleransi Beragama”, Ormas Gerakan Masyarakat Penerus Bung Karno, di Hotel Borobudur Jakarta, 13 Februari, 2014., 2014.

4 Nana Syaodih Sukmadinata, Metode Penelitian Pendidikan (Bandung: Remaja Rosdakarya, 2009). 
referred to as naturalistic research methods because their research is carried out under natural conditions 5. Because of its natural nature, qualitative research means many things for many people6.

To get a broad and profound picture of SMP Muhammadiyah and its tolerance teachings, the data was collected using natural settings as direct data sources. According to Muhadjir (1996) there are two types of data in this study, namely primary data and secondary data. Primary data is obtained in the form of verbal words and behaviors from the subject (informant) relating to the school and the concept of religious tolerance. While secondary data comes from documents, photographs and other objects that can be used as a complement to primary data. The characteristics of secondary data are in the form of writings, recordings, pictures or photographs that are related to the research focus. Data collection techniques are used to obtain data acquisition holistically and integratively, and pay attention to the relevance of the data with focus and purpose (Mungin, 2001: 17). The techniques used were: (1) in-depth interviews (independent interview), (2) observation of participants, and (3) documentation study.

\section{Tolerance in Religion and Nationalism}

In Arabic, tolerance is often referred to as tasamuh. Tolerance or tasamuh has the same meaning as harmony. Tolerance is a readiness and inner ability to be at home with other people who differ substantially even though there is a conflict

5 E. G. Lincoln, Y. S., \& Guba, Naturalistic Inquiry (CA: Sage: Beverly Hills, 1985).

6 Shirley Agostinho, "Naturalistic Inquiry in E-Learning Research," International Journal of Qualitative Methods 4, no. 1 (2005): 13-26, https://doi.org/10.1177/160940690500400102. 
with an understanding of what is good and a decent way of life 7 . Difference is a necessity in life. Plurality as absolute reality can no longer be ignored or rejected. There is no more power in modern times that can negate plurality. What can be done by people, from cultural or religious groups, is to accept this as part of a living life. Positive and objective acceptance of plurality creates the concept of pluralism 8 .

It was further emphasized that tolerance comes from the Latin language tolerare which means restraint, being patient, letting other people think differently, wide-hearted and tolerant towards people with different views, beliefs, and religion 9. Some definitions of tolerance as described by Mawardi (2008: 94) is a form of accommodation that does not require settlement from other parties because both parties are equally aware of each other and expect a conducive situation. In another concept, religious harmony is the creation of a harmonious and dynamic relationship and harmony and peace among fellow religious people in Indonesia 10.

There are three different orientations in religion and ethnic identity. They are exclusive, inclusive and pluralist groups. Exclusive group are group that build enclaves, namely people who always state that there is only one way to understand the reality and interpret the sacred. On the contrary, group with inclusive views believes that among many traditions,

7 Zakiyuddin Baidhawy, Pendidikan Agama Berwawasan Multikultural (Jakarta: Penerbit Erlangga, 2005).

8 Christian Siregar, "Pluralism and Religious Tolerance in Indonesia : an Ethical-Theological Review Based on Christian Faith Perspectives," HUMANIORA JOURNAL 7, no. 3 (2016): 349-58.

9 Mukti Ali, Pluralisme Agama di Persimpangan Menuju Tuhan (Salatiga: STAIN Salatiga Press, 2006).

10 Yustiani, "Kerukunan antar Umat Beragama Kristen dan Islam di Soe, Nusa Tenggara Timur," Jurnal Analisa XV, no. 02 (2008): 71-84. 
communities and the truth of religion, there is one tradition that becomes the top of other superior and comprehensive traditions. While the pluralist group believes that truth does not only belong to a particular tradition or community 11 .

The order of community life consists of various factors. One of them is a religion factor. The religions in the world are very diverse and of course each religion has the truth claim. Each truth is in accordance with the principles of their teachings and beliefs. Every religion teaches goodness, greeting each other, and understanding, respecting and appreciating even those of different faiths.

Factors triggering conflicts between and within religious communities include; a) in the form of superficial, fanatical and textual understanding of the teachings of his religion, which in turn has an impact on a narrow perspective on a religious teaching; b) there is a movement to resolve the problem of interfaith differences with conflict; Conflict is as an expression for the limitations of fulfilling the needs of life for the perpetrator because of the source of living factors, poverty, and social disharmony.

Every religion also teaches how to undergo a relationship that is vertical and horizontal. The vertical relationship is the relationship of human/creature with God and horizontal relationship is relationship of a human with the others and the natural surroundings. Both of them have the meaning "mutual understanding and respect". The popular term often used in society is tolerance. In the view of Islam, it is often termed as tasamuh which at the end, it will create harmony of life even

11 Zakiyuddin Baidhawy, Konsep Jihad dan Mujahid Damai (The Concept of Jihad and Mujahid of Peace), Cet ke 1 (Jakarta: Kementerian Agama RI. Direktorat Jenderal Pendidikan Islam Direktorat Jenderal Pendidikan Tinggi Islam, 2012). 
though there are differences. In this case what is meant by tolerance is social harmony.

Islam as a religion that carries the principle of rahmatan lil 'alamin is certainly highly upholds the values of tolerance. In the context of Indonesia, it can be said that the term of plurality will be a real and empirical experience that is very concrete. It can be seen from how the nation is very multicultural, whether from ethnicity, race, tradition, customs, religion and belief, and so on. From the various components of the nation, Marpuah in Balitbang Agama Jakarta 12 states that the principle of pluralism is an understanding that respects the existence of differences among human beings, which is further recognized and preserved in the form of slogan "Bhinneka Tunggal Ika" or Unity in Diversity. It proves that Indonesia is highly promoting the value of pluralism to create peace and togetherness.

This is in line with the opening text of UUD 1945 (Indonesian Constitution) that the main principle of the establishment of this nation is to advance the general welfare, educate the life of the nation, and participate in carrying out world order based on independence, lasting peace and social justice 13 . Without peace, it is impossible to achieve those goals. In this aspect, Zakiyudin Baidhawi formulated seventeen aspects of peace value. Those Seventeen values are: tauhid (one God), ummah (living together), rahmah (loving one another), musawah (equality), ta'aruf (co-existence), tafahum (understanding one another), takrim (respecting one another), fastabiqul khairat (fair competition in good deeds), amanah (honesty), husnuzzan

12 Tim Penulis Balai Litbang Agama Jakarta, Konflik \& Penyelesaian Pendirian Rumah Ibadah (Jakarta: Balai Penelitian dan Pengembangan Agama Jakarta, 2015).

13 Notonagoro, Pancasila; Dasar Falsafah Negara (Jakarta: C.V. Pantjuran Tudjuh, 1974). 
(positive thinking), tasamuh (tolerance), 'afw (forgiving), sulh (reconciliation), islah (conflict resolution), silah/ salam (peace), lain (non-violence), dan ' $a d l$ (justice)14. It was clear that the nation's founding fathers want to uphold their strengths how to formulate the system of the nation and state life that emphasizes the values of tolerance for the multicultures and diversity.

Nationality insight is a big spirit from the citizens to always overcome differences together. Before Indonesia get independence, there had been organizations such as Boedi Utomo that made a point of departure for the youth oath or sumpah pemuda. If we look at sumpah pemuda verse-by-verse, the words are a reflection of the spirit of the unity of the people in a difference which is tied with a main goal of "freedom of state".

Religion and state or nationality is like twins. If religion is sustained by the state/nationality, religion will be strong and rise in the personal soul and vice versa respect. Religion has medicine. People whose the authority to give medicine are a pharmacist and a doctor. It must be given according to its portion as a solution to the problem of making people safe. According to Natsir, religion (Islam) does not merely regulate human relations with their God, but also regulates humans and humans. Natsir considers that the state is an institution, an organization that has a purpose, complete with physical facilities and specific norms that are generally recognized 15.

Various formulations of the way to create the world peace need to be clarified, understood, internalized and implemented

14 Zakiyuddin Baidhawy, "Building Harmony and Peace Through Multiculturalist Theology-Based Religious Education: An Alternative for Contemporary Indonesia," British Journal of Religious Education 29, no. 1 (2007): 15-30.

15 Budiyono, "Hubungan Negara dan Agama dalam Negara Pancasila," Fiat Justisia Jurnal Ilmu Hukum 8, no. 3 (2014): 410-23. 
together. Living in conflict is not possible to prosper the community. On the contrary, living in a peaceful atmosphere will increasingly open the way to get a better direction. Readiness to accept each other, respect each other and want to live peacefully are the main requirements 16 .

\section{The Role of Religious Education Institutions on Harmony}

SMP Muhammadiyah Salatiga as part of an educational institution managed by one of the largest Islamic Organizations in Indonesia, which in its structure is under the Ministry of National Education certainly has the same objectives as the National education goals. Based on Law Number 20 of 2003 concerning the National Education System, Article 3, the aim of national education is to develop the potential of students to become faithful and fearful people to God Almighty, noble, healthy, knowledgeable, capable, creative, independent, and become a democratic and responsible citizen.

From the formulation of national education goals above, it is clear that the education process seeks to realize people who are faithful and devoted to God and have noble character, become democratic and responsible citizens. But history says that many religious conflicts originate from the background of differences in religious understanding. In this case, the role of religious/educational institutions and religious knowledge/understanding have the potential to cause internal and external, horizontal and vertical conflicts 17 . On the contrary,

16 Hilman Latif \& Zezen Zaenal Muttaqin, ed., Islam dan Urusan Kemanusiaan: Konflik, Perdamaian dan Filantropi (Jakarta: PT. Serambi Ilmu Semesta, 2015).

17 Puspo Nugroho, "Pendidikan Kerukunan Umat Beragama, telaah Konsep Kerukunan Umat Beragama Perspektif Pendidikan Islam," Mudarrisa: Kajian Kependidikan Islam 4, no. 2 (2012): 273-93. 
although there are still differences in understanding and beliefs that cannot be avoided, if a society has a harmonious spirit, tolerant willingness to respect different things, it will create peace.

Insights on religious harmony or in Islam term Tasamuh/Tolerance is no longer a new item for Islamic education institutions under the auspices of the Muhammadiyah community organization. Tolerance or tasamuh values become a core part of what is taught to students. This is stated in the standard book of Al Islam education and Kemuhamadiyahan, that the purpose of education at SMP Muhamadiyah is one of which is to realize Indonesian people who are religious and have good character, namely knowledgeable, diligent in worship, intelligent, productive, creative, honest, fair, ethical, disciplined, tolerant (Tasamuh), maintaining personal and social harmony and developing Islamic culture within the school community in accordance with the Qur'an and Al Hadist.

Al Islam and Kemuhammadiyahan Education emphasize balance and harmony in relations between human with Allah SWT, human with human, human with oneself and human with the environment in accordance with the Qur'an and Sunnah. The role of SMP Muhammadiyah Salatiga as one of the institutions based on religious education has been carried out in every aspect of the content and process.

Three phases of the tasamuh education process as an effort to cultivate the values of tolerance in the Religious Education Institute of SMP Muhammadiyah in Salatiga are: First, related to the terms of religious harmony in curriculum context, secondly; educator's understanding of religious tolerance, third; implementation of religious harmony education. These points will be studied in depth as follows: 


\section{Tolerance Education in Institutional Curriculum Contents}

From the results of observations, the implementation of tolerance values in the curriculum has become an integral part of the entire curriculum. In particular, the tendency of tasamuh values to be seen is more visible in the Islamic Religion family, especially the moral lessons of the noble moral sub-themes. These subjects explicitly stated a chapter that discusses tasamuh or tolerance. But it does not rule out the possibility because the subject of religious harmony is part of character education that is hidden. Each subject has a distinction to include these tasamuh values into one part within the scope of religious subjects.

In addition to its nature contained in the (hidden) curriculum content, the headmaster said that they hold various activities that are able to develop potential students according to their interests and talents in accordance with Islamic Principles. These activities include OSIS organization, arts, drum bands, tapak suci, scouting, orphanage and other social activities that have been running.

In accordance with the institution's vision and mission, each subject is required to engage in dialogue with various local, regional, national and global issues and situations. Every curriculum and syllabus of subjects is made in interconnection and integration with other sciences that contains the values of tolerance, humanity, character and the most important values, akhlaqul karimah. In other words, the curriculum and syllabus have contained the values of religious harmony in order to create mutual respect and compassion among fellow human beings even though they are hidden. Some subjects that explicitly 
contain the values of religious harmony include Akhlaq, Tarikh, Sejarah Islam, PPkn and Kemuhamadiyahan. Each subject discusses the values of the Islamic teachings with various cultures that develop their relationship with nation and state.

Religious subjects, for example in SMP Muhamadiyah, are divided into 6 scope. They are Al-Qur'an dan Hadist, Aqidah, Akhlaq, Fiqih (worship and mu'amalah), Tarikh dan kebudayaan Islam, and Kemuhammadiyahan. From the six scopes of the Islamic Religion subject, there are several subjects that contain the values of religious harmony. It is stated in the standard of competence and basic competency in class IX Akhlaq subject such as getting used to behaving commendably in Tasamuh/tolerance and Tarikh Kebudayaan Islam subject in class VII like the mission of the Prophet Muhammad as the bearer of the teachings of Islam Rahmatan lil Alamin for human civilization.

This situation does not limit teachers to continue to instill values of religious harmony. In addition to the PPKN teachers, the responsibility of teaching the values of religious harmony is also a shared responsibility of all levels of the academic community in the School. In this position, it can be seen that the values of character, respect, tolerance or tasamuh become hidden curriculum.

The main essence of life in the world is none other than seeking supplies for the salvation of the world and the hereafter. In this case, Islam regulates all procedures for living, socializing, strengthening Ukuwah Islamiyah, Islamic brotherhood, ukhuwah wathoniyah and ukuwah basyoriyah insaniyah. Islam as a religion of rahmatan lil alamin must appear as a religion that carries peace. In accordance with his presentation, the teachers also believe 
and argue that religions have the same mission, namely salvation for humanity. Each religion has a common point to always teach the values of goodness, peace, respect and fairness to others whether in one religion or different religions.

The importance of each educator must contribute in preparing future generations who are able to accept and respect pluralism as an effort to maintain the integrity of the Republic of Indonesia. From the results of the observation and interview data, the writer draws the conclusion that the educators in SMP Muhammadiyah are very eager to create the unity of the Republic of Indonesia. Responding to some organizations that are trying to make this country an Islamic khilafah state, they do not agree. Teacher or vice head of students explained:

“..ya tidak bisa...hal tersebut jelas tidak mungkin karena Indonesia berdasarkan Pancasila dan Undang-Undang dasar 45 selain itu melihat keadaanya Indonesia ini sangat majemuk. ("... it can't ... it is certainly not possible because Indonesia is based on Pancasila and UUD '45, besides seeing the condition of Indonesia which is very diverse"

The state of Indonesia has similarities with Arab, especially Medina at that time, where the population consisted of multi-races, multi-ethnic and religions. What the Prophet Muhammad SAW did was fostering the people of Medina to live side by side with adherents of other religions. However, the Prophet Muhammad did not later give the name Medina with an Islamic state or Islamic kingdom, but how Islam was able to merge in various aspects. 
In Indonesia, matters related to governance and public relations are based on Pancasila philosophy and the 1945 Constitution. Pancasila and UUD 1945 are as consensus that binds pluralism in one unit of the Unitary Republic of Indonesia, Unity in Diversity, as we often see on the symbol of our country, garuda or eagle. Indonesia is not an Islamic state, while changing the Indonesian state in the form of the Republic is one of the things that will actually have an impact on the nation's disintegration and destruction and hurt the spirit of sacrifice and ideals of the nation's fighters who have sacrificed their lives and bodies to fight for the country's independence.

Salatiga, which is well-known as a transit city cannot possibly be separated from a social interaction, whether it is in agreement or different understandings. Humans are social beings who always need others, help each other, live in a community, organize and interact even though there are differences. Related to this point, making the tolerance/tasamuh term become important and very urgent in the life of the current global era. SMP Muhamadiyah tries to interpret the values of tolerance through an integrated and sustainable curriculum structure to create a safe and peaceful Indonesia. With curriculum content that is full of tolerance values, students are expected to implement it in their daily lives.

\section{Teacher's Understanding about Religious Tolerance}

The discussion on the theme of religious harmony education and how that process of in SMP Muhamadiyah Salatiga is inseparable from how the understanding of teachers as agents of change in this theme is. In the term Islam which is better known as tasamuh, tolerance is not a 
new thing, but the problem is that it always stretches and becomes a kind of wild ball that at any time can warm up and heat up or even explode and cool down.

Geographically, Indonesia as a country that is not only multi-ethnics but also multi-religions puts. It is as a dilemmatic issue and that conditions will have various consequences if there is no solution. Religious harmony will not be separated from plurality. This plurality becomes sunatullah; plurality of skin colors, ideologies, opinions, ethnicities, religions and other differences. In some of these pluralistic areas, sometimes it is not uncommon to trigger intolerance which eventually develops into radicalism.

Related to pluralism, some teachers argued that they strongly disagree about the existence of pluralism that considers all religious teachings to be the same. An assertive statement was conveyed by one of the religious teachers that there is an ideology that developed at this time and according to him, it is very dangerous.

"... liberalisme dan pluralisme, kita harus berhati hati betul". Kalau pluralisme memandang seтиa agama baik dan benar jelas kami tidak setuju. Kalau sudah menyangkut faham dan menyangkut aqidah, keyakinan dalam ajaran Muhammadiyah dengan tegas menolak, tapi kalau pluralitas kami mengakui dan bisa menerima.. ("....liberalism and pluralism, we must be very careful". If pluralism views all religions is good and right, we do not agree. When it comes to understanding and relating to aqidah, the belief in the teachings of Muhammadiyah firmly rejects, but if plurality, we acknowledge and can accept...

The statement above shows that the teacher's understanding of plurality is a necessity that cannot be avoided. Plurality 
is diversity with different colors and patterns. Related to the instilling of Islamic teachings about religious harmony/ tolerance, it is divided into two types, namely tolerance among people in one religion and tolerance with other religions. Related to the internal tolerance, one of teachers suggested:

"sebagaimana apa yang diteladankan oleh nabi itu lah yang kami jalankan. Adapun hubungan kita terhadap internal agama Islam meskipun tidak bisa kita pungkiri terdapat perbedaan khilafiah, kita juga harus tetap baik. Dalam menyampaikan suatu ajaran yang didalamnya terdapat sebuah perbedaan, kita tetap harus menghargai kelompok lain, tetap menjaga ukhuwah islamiyah serta hubungan antar organisasi masyarakat Islam. Hal tersebut diatur dalam kepribadian Muhamadiyah dengan istilah "muamalah duniawiyah". Dalam mu'amalah duniawiyah ini diatur landasan kepribadian bagaimana seharusnya manusia itu berhubungan dengan orang lain.

("We do like what was done by the prophet. Related to our relationship to the internal religion of Islam, we cannot deny that there are differences in khilafiah. We must do well. In conveying a teaching with differences, we still have to respect other groups and maintain Islamic brotherhood and relations between Islamic community organizations. It is arranged in the personality of Muhamadiyah with the term "Muamalah Duniawiyah". Mu'amalah duniawiyah manages the personality base of how humans should relate to others).

One of teachers add: 
"apabila ormas-ormas Islam yang ada di Indonesia seperti NU dan Muhammadiyah dapat bersatu akan tercipta ukhuwah Islamiyah yang lebih baik. Upaya pernah diselenggarakan sebuah kegiatan pengajian bersama antar NU dan Muhammadiyah, meskipun masih sebatas sampai pada pengurus atas saja ...... “ ("If Islamic organizations in Indonesia such as NU and Muhammadiyah can unite, there will be a better Islamic brotherhood. There was an effort to hold a joint study activity between NU and Muhammadiyah even though it was still limited to the top structure ... ")

Although there are differences in internal religion, Muhammadiyah people continue to uphold the value of tolerance. With these differences, God gives His mercy. The process of implementing the values of tolerance between and within religious communities has been carried out and lived by the teachers. This is evidenced by the form of activities carried out by one of the teachers who became imam of the study in a pluralistic area with various ideals and schools. It indicates that the Muhammadiyah generations have implemented religious tolerance as a fortress as well as an effort to overcome the inclusion of irresponsible individuals who want to destroy the peace, tranquility of this nation even those who intend to divide Indonesian Muslims.

Related to the attitudes and views of teachers in SMP Muhammadiyah Salatiga towards other religious communities, there is a number of provisions which becomes the basic values and foundations: Firs, as a Muslim, it is not permissible to force others to join Islam. This is as the implementation of the Word of God QS Al 
Baqoroh Ayat 256 "la ikroha fiddin". Second, as a Muslim, we must acknowledge the existence of other religions and guarantee the freedom to embrace religion. Because it is a provision of Allah, prohibition of denouncing and cursing everything that becomes the worship of others. Third, do good things to those who have different beliefs and religions in worldly affairs such as trade, sale and purchase agreements as long as they do not fight and hostile to Islam. The ability to do goodness is only limited to the relationship of mu'amalah. The relations of Aqidah and worship are strictly prohibited in Islam. Doing goodness to anyone (people of other religions) as long as they are not hostile and disturbing is allowed. Fourth, appreciate and respect the beliefs of others while maintaining the principle of monotheism as a Muslim or in Islam is the truest religion for Allah.

As an Islamic generation, especially educators must show good attitude towards other religious communities so that harmony and peace can be created. "The important thing is that our attitude towards the people of other religions must be good while they do not disturb and interfere our religion." The tolerance taught is the command to always do goodness and act fairly and respect the beliefs of others.

According to one teacher, tolerance means not justifying all religious beliefs and being free to adhere to them, but tolerance confirms that in Indonesia there are other religions besides Islam that must be respected. But a Muslim must have a truth claim and cling to the Qur'an which has affirmed that the religion that will be accepted by Allah is only Islam (innaddiina 'inda Allahi al islam) (Interview, 2014). Likewise with adherents of other religions, they must have the belief that this religion what 
they profess is the best. This is the basis for carrying out every religious activity in accordance with their respective religions. The above explanation is corroborated by the results of the researcher conducted Baidhawy on the typology of tolerant teachers:

...Guru toleran percaya bahwa Allah menganggap Islam sebagai satu-satunya agama yang benar, dan akibatnya bahwa agama-agama selain Islam ditolak oleh Allah. Namun, kelompok ini juga percaya bahwa keberadaan dan ajaran agama lain harus diakui dan dihormati, karena mereka seтиa dilindungi oleh konstitusi Indonesia (Undang-Undang Dasar 1945). Guru-guru toleran melihat kebebasan beragama sebagai bagian dari hak asasi manusia, dan karena itu percaya bahwa umat Muslim harus menghormati agama dan kepercayaan orang lain, namun tetap setia kepada Islam. Para guru toleran mendorong saling menghormati dan membangun hubungan baik antara Muslim dan non-Muslim di ranah interaksi sosial di antara sesama manusia ( $h$ \}abl min an-na>s) 18

(... Tolerant teachers believe that God regards Islam as the only true religion, and consequently that religions other than Islam are rejected by Allah. However, this group also believes that the existence and teachings of other religions must be recognized and respected, because they are all protected by the Indonesian constitution (Undang-undang Dasar 1945). Tolerant teachers see religious freedom as part of human rights. Muslims must respect the other religions and beliefs, but

18 Zakiyuddin Baidhawy, "Pendidikan Agama Islam Untuk Mempromosikan Perdamaian Dalam Masyarakat Plural," ANALISIS: Jurnal Studi Keislaman 14, no. 2 (2014): 289-310. 
they must keep loyal to Islam. Tolerant teachers encourage mutual respect and build good relations between Muslims and non-Muslims in the realm of social interaction among human beings (hlabl min an$n a>s) 19$

Seeing the above condition, educators instill in students that their beliefs should not give rise to hostility, hatred, opposition or coercion in religious beliefs and in the life of the nation and state.

\section{Forms of Institutional Activities on Religious Tolerance} One form of real tolerance has been carried out by SMP Muhammadiyah Salatiga namely the participation of religious teachers in additional education in the form of a collaboration involving other religious education institutions. This was carried out during the month of Ramadan, which was a spiritual activity conducted by SMP Stella Matutina Christian Salatiga. From the results of interviews with school principals, it was obtained that we (religious teachers of SMP Muhammadiyah Salatiga)) were involved in spiritual activities at SMP Stela Matutina Christian in Salatiga with the aim of providing Islamic religious education.

On another occasion, there was a form of cooperation in MGMP activities involving all levels of general teachers in Salatiga City both in same and different religions. Although certain respects interacting with other religions, a Muslim must have the idea that the religion that will be accepted by Allah is only Islam. This is why a Muslim must have a strong foundation, in terms of the word Thrut Claim = Inna addina 'inda Allahi al islam.

If there is an attitude of suspicion, the negative nature of other people will certainly hamper the creation of harmony between

19 Baidhawy. 
religious communities. The point is that as Muslims, we must be able to apply the principle "Lakum di nukum waliyadin" (to you, your religion and to me, my religion) accompanied by an attitude of no blame or negative thinking on other parties.

A teaching will not be easy like what is wanted if a teacher is also less aware of the themes discussed. The term tolerance is also like that. If a teacher does not know what and how tolerance is, it will be very difficult to be applied. The understanding of a student depends on how the teacher understands and how the teacher presents it. One form of understanding is tangible evidence of an event that is a requirement for a value contained in it. It is like a real experience. Experience is the most valuable teacher and being a teacher is a very valuable experience.

We need harmony in the current millennia era. One of the keywords that determine the success or failure of the effort to maintain the multicultural Indonesian National Unity is religious tolerance. This was confirmed by the opinion of one teacher. According to his explanation "Toleransi itu sangat perlu sekali, bila tidak ada toleransi bisa memecah persatuan dan kesatuan bangsa (Tolerance is very necessary. If there is no tolerance, it can break the unity of the nation)". According to the writer, it is not only to strengthen the unity of the nation, but with the understanding and implementation of tolerance attitudes, it will avoid radical and intolerant ideologies.

Related to the environmental conditions of SMP Muhammadiyah itself, the teacher explains that the community in the neighborhood around the School is the majority of Non-Islamic religions. Nevertheless, the school still upholds the attitude of tolerance. One teacher added "kita (pihak sekolah) juga berhubungan baik dengan warga sekitar, kami melakukan kerjasama dengan perangkat $R T$ $R W$ guna memberikan pengertian dan kerjasama yang baik 
kepada para pemilik warung yang beragama non muslim disekitar sekolahan yang biasa dijadikan tempat istirahat anak-anak" (we also have good relations with the local people, we collaborate with RT RW to give understanding and good cooperation to the stall owners who are nonMuslim around the school which is commonly used as a children's resting place). This is a real proof of a form of tolerance and togetherness of the school with the surrounding environment so that it is hoped that communication and good relations with the community will be established.

Seeing the reality that exists, as a Muslim,, we cannot stay away or even close ourselves to other religions or different beliefs. During this time, we also feel and enjoy products made by others who have different beliefs and religions. We also often socialize with other people. This is same with the observations done by the writer at the research location and from the responses of several teachers. Just like motorbikes, cell phones, computers and various technologies even food that has been made, we indirectly or unconsciously feel the benefits and we cannot possibly escape from it. This reality is as evidence that we must not be narrow-minded, exclusive both internally and externally from religious people. The existence of a tolerance attitude in Muhammadiyah educational institutions will be able to provide inspiration for other religion-based educational institutions in the development of educational progress today and in an effort to strengthen the unity and integrity of the nation. 


\section{Internalization of Religious Tolerance Values in Teaching and Learning Process}

For the good purposes, education is actually considered an important instrument. Because education up to now is believed to have a big role in shaping the character of individuals who are educated and able to become "guiding light" for the young generation of the nation's future. Through its education system, a tolerance-based education will try to nurture and strive to foster an inclusive understanding of students. With an orientation to give awareness to the students about the importance of respecting, respecting and collaborating with other religions through the teachings of the aqidah, it is necessary to emphasize the importance of religious "brotherhood".

In the subject of Aqidah, student implement of faith in daily life. In essence, Aqidah must follow with good deeds or morals al-Karimah for students, have good character in God, nature and fellow human beings. One teacher explained "..saya hanya sebatas menerangkan rukun iman. Itupun waktunya sangat kurang, habis di materi...kalau masalah toleransi itu pada mata pelajaran akhlaq.. ("... I only explained the articles of faith. The time is very lacking, it runs out in the material ... related to tolerance, it is in Akhlaq subject..)". Seeing the reality, there should be additional learning time and displaying religious education and the focus is not just ritual and belief abilities, but also at the level of social and human morality.

In the teaching and learning process, the teacher has important duties. The teacher also determines the success of a learning process. Teachers who have qualifications will produce qualified outputs. To foster students to become tolerant human beings whose broad insight into religion and always strive to realize a harmonious religious life, teachers are also required to be professional and tolerant. 
In the Akhlaq education program, it is studied how to get accustomed to behaving admirably, having good morals with fellow Muslims or with different religions. With this subject, it is expected to be able to understand the importance of the presence of other people who even have different beliefs and religious teachings with us so that they can be tolerant, willing to respect the rights of others and members of society in one country. While the subject Tarikh and Kebudayaan Islam examines that Islam brought by our Prophet Muhammad p.b.u.h. is Rahmatan Lil Alamin. Here, it is confirmed that Islam is present for all humanity without exception.

In SMP Muhammadiyah institutions, the values of religious harmony by educators have been internalized in every learning process and academic culture in the school environment. But they are explicitly emphasized in certain subjects that have direct links. For other subjects that are as hidden curriculum, the theme of the study discussed has relevance with the theme of harmony.

This is understandable because in terms of policy, there is no specific guidance and particular emphasis on teachers when teaching. The term of harmony is more focused on religious teachers because according to the syllabus and the material being taught. It does not rule out the possibility that other teachers will include term of religious harmony in their subjects, but this is limited.

According to the presentation of the curriculum vice head, the values of religious harmony are instilled to their students in teaching and learning activities or Kegiatan Belajar Mengajar (KBM). According to the explanation of one of the teaching staff, the internal harmony of Muslims in Fiqh lesson is instilled by:

“... cara menyampaikan kepada anak anak saya kemukakan sumber dasarnya dengan menjelaskan sejarah yang benar. Terlepas dari perbedaan khilafiah...akan tapi 
jika ditemukan hal yang berbeda, jika kamu sudah terbiasa dengan amaliah ти ya jangan sampai kamu menyalahkan menentang lingkunganmu. Dalam mengenalkan pada anak kami kemukakan dasarnya dulu, ...kalau kamu belum memiliki dasar dan sejarahnya ikutilah tetapi jangan sampai menentang...,asal orang itu komitmen dengan apa yang ia yakini."

"... I explain the true history as the basic source to my students. Regardless of the difference in khilafiah ... but if you find something different, if you are familiar with your amaliah, don't let you blame your environment. In introducing it to our children, I put forward the basics first: ... if you don't have the foundation and history, follow it, but don't oppose it ... as long as the person is committed to what he believes in."

This is done without force so that the students will know more, understand better and expected to be tolerant towards different Muslims, how to worship, because they know what they are like. For this reason, in order to create a harmonious relationship between religious communities, there must be elements that are realized. The teachers instill in students the attitude of respecting the rights and beliefs of others, accepting a variety of differences and trying to foster mutual understanding among people.

For tolerance related to other religions as well as responding to emerging issues such as when the Christmas holidays or other religious festivals come with a view to appreciating such as giving congratulations to other religions, it is not permitted. According to the explanation of one teacher in Islamic Education subject in the same occasion "Kami tidak mengajarkan serta tidak membenarkan pemberian ucapan selamat terhadap umat agama lain atas perayaan hari raya mereka, karena bila kita memberi selamat berarti kita secara tidak langsung ikut mengiyakan dan 
membenarkan agama mereka. (We do not teach and do not justify giving congratulations to people of other religions for the celebration of their feasts, because if we congratulate we indirectly join in affirming and justifying their religions"

In the learning process, we introduce its history, the origin of an event such as the valentine culture sponsored by the Western countries (non-Islamic) and said to be a day of love but the real evidence is that there are many disadvantages for young people or Anak Baru Gedhe (ABG). By giving good direction on how to be wise as a Muslim, students will understand more about how to react.

One of Pendidikan Kewarganegaraan (civil education) subject teachers explained "agama Islam sebagai pegangan dasar, adapun tentang toleransi berkenaan dengan hubungan bermu'amalah, bermasyarakat, berbangsa dan bernegara"..."Untuk menjaga diri kita, sebagai seorang muslim harus mempunyai dasar landasan/ pondasi iman yang kuat dan harus faham betul terlebih dahulu dengan agama kita sendiri". (Islam is the basis and grip. Tolerance is only limited to the relationship of mu'amalah, community, nation and state" ... "To protect ourselves, as a Muslim, we must have a strong foundation of faith, we must understand our own religion well first)

For the method of instilling the value, one teacher explained the methods used are various and depend on the teacher. According to one teacher, how to cultivate tolerance values is usually through minor habituation towards fellow Muslims, giving a real example in daily life with the Contextual Teaching and Learning (CTL) story method. Another teacher added "..Anak disuruh untuk menulis pengalaman-pengalaman keseharian baik pengalaman diri sendiri maupun pengalaman orang lain disekitarnya seperti sebuah tugas portofolio yang nantinya dijadikan bahan diskusi. Anak diajak berimajinasi 
serasa terjun langsung dalam kehidupan yang akhirnya serta memberi tanggapan baik buruk tentang permasalahan tersebut." ("... students are asked to write the daily experiences both their own experiences and the experiences of other people around them such as a portfolio assignment which will later be used as discussion material. Students invited to imagine as if they were directly involved in the lives and gave the good or bad responses to the problem.)

Strategy in teaching tolerance is to develop an attitude of empathy. In addition, the teacher also made several statements relating to the theme which later the students must give their responses. The teacher conveyed the arguments both naqli's argument and aqli's argument about the theme and how we, as servants of Allah SWT, implement it in our daily lives.

\section{Conclusion}

The main principle of internalizing the values of religious tolerance is instilling the students to apply the principle of reciprocity. It is like a reciprocal relationship. For example, if you do not want to be pinched, then do not pinch; if you do not want to be hurt, then do not hurt. This is in line with the attitude of impoliteness or violence against people who are different in beliefs with us. They will turn to attack and behave impolite towards our beliefs if we do it to them. Surely, as Muslims, we do not want it happen because Islam explicitly teaches peace and compassion. Moreover, all those religions also teach peace and love. This is affirmed by some teachers that many religions have the same mission, namely the salvation of the world and hereafter to human who are as its followers; teach the values of kindness, peace and respect. If every educational institution is based on religion, religion is able to contribute not only the transfer of knowledge but the same values, vision and mission, creating 
world peace as mandated in UUD 1945, there will be future generations who have a tolerant spirit, appreciate every difference and have the humanist soul or akhlakul karimah.

Through such an educational atmosphere, there will be a harmonious atmosphere in religious life and there is no meaningful difference between human "differences" which in reality are different. There is no superior or inferior. And there will be atmosphere of dialogue that creates new spiritual insights about religion and the benefit in each person's life.

\section{Reference}

Agostinho, Shirley. "Naturalistic Inquiry in E-Learning Research." International Journal of Qualitative Methods 4, no. 11 (2005): $13-26$. https://doi.org/10.1177/160940690500400102.

Ali, Mukti. Pluralisme Agama di Persimpangan Menuju Tuhan. Salatiga: STAIN Salatiga Press, 2006.

Asshiddiqie, Jimly. "Toleransi Dan Intoleransi Beragama Di Indonesia Pasca Reformasi.” Dialog Kebangsaan tentang "Toleransi Beragama", Ormas Gerakan Masyarakat Penerus Bung Karno, di Hotel Borobudur Jakarta, 13 Februari, 2014., 2014.

Baidhawy, Zakiyuddin. "Building Harmony and Peace Through Multiculturalist Theology-Based Religious Education: An Alternative for Contemporary Indonesia." British Journal of Religious Education 29, no. 1 (2007): 15-30.

. Konsep Jihad dan Mujahid Damai (The Concept of Jihad and Mujahid of Peace). Cet ke 1. Jakarta: Kementerian Agama RI. Direktorat Jenderal Pendidikan Islam Direktorat Jenderal Pendidikan Tinggi Islam, 2012. 
- Pendidikan Agama Berwawasan Multikultural. Jakarta: Penerbit Erlangga, 2005.

—. "Pendidikan Agama Islam Untuk Mempromosikan Perdamaian Dalam Masyarakat Plural." ANALISIS: Jurnal Studi Keislaman 14, no. 2 (2014): 289-310.

Budiyono. "Hubungan Negara dan Agama dalam Negara

Pancasila." Fiat Justisia Jurnal Ilmu Hukum 8, no. 3 (2014): 410-23.

Iannaccone, Laurence R., dan Eli Berman. Religious Extremism: The Good, the Bad, and the Deadly. Public Choice. Vol. 128, 2006. https://doi.org/10.1007/s11127-006-9047-7.

Lincoln, Y. S., \& Guba, E. G. Naturalistic Inquiry. CA: Sage: Beverly Hills, 1985.

Mutiara, Kholidia Efining. "Menanamkan Toleransi Multi Agama sebagai Payung Anti Radikalisme (Studi Kasus Komunitas Lintas Agama dan Kepercayaan di Pantura Tali Akrab)." Fikrah: Jurnal Ilmu Aqidah dan Studi Keagamaan 4, no. 2 (2016): 293-302.

Muttaqin, Hilman Latif \& Zezen Zaenal, ed. Islam dan Urusan Kemanusiaan: Konflik, Perdamaian dan Filantropi. Jakarta: PT. Serambi Ilmu Semesta, 2015.

Notonagoro. Pancasila; Dasar Falsafah Negara. Jakarta: C.V. Pantjuran Tudjuh, 1974.

Nugroho, Puspo. "Pendidikan Kerukunan Umat Beragama, telaah Konsep Kerukunan Umat Beragama Perspektif Pendidikan Islam." Mudarrisa: Kajian Kependidikan Islam 4, no. 2 (2012): 273-93. 
Siregar, Christian. "Pluralism and Religious Tolerance in Indonesia: an Ethical-Theological Review Based on Christian Faith Perspectives." HUMANIORA JOURNAL 7, no. 3 (2016): 349-58.

Sukmadinata, Nana Syaodih. Metode Penelitian Pendidikan. Bandung: Remaja Rosdakarya, 2009.

Tim Penulis Balai Litbang Agama Jakarta. Konflik \& Penyelesaian Pendirian Rumah Ibadah. Jakarta: Balai Penelitian dan Pengembangan Agama Jakarta, 2015.

Yustiani. "Kerukunan antar Umat Beragama Kristen dan Islam di Soe, Nusa Tenggara Timur.” Jurnal Analisa XV, no. 02 (2008): 71-84. 